\title{
Review
}

\section{Role of soil microbes in sustainable crop production and soil health: A review}

\author{
K.K. Shah ${ }^{1 *}$, S. Tripathi ${ }^{2}$ I. Tiwari², J. Shrestha ${ }^{3}$, B. Modi ${ }^{4}$, N. Paudel ${ }^{5,6,}$ B.D. Das ${ }^{7}$ \\ ${ }^{1}$ Institute of Agriculture and Animal Science, Gokuleshwor College, Tribhuvan University, Nepal \\ ${ }^{2}$ Himalayan College of Agricultural Science and Technology, Purbanchal University, Kathmandu, Nepal \\ ${ }^{3}$ Nepal Agricultural Research Council, National Plant Breeding and Genetics Research Centre, Khumaltar, Lalitpur, Nepal \\ ${ }^{4}$ Central Department of Chemistry, Tribhuvan University, Kathmandu, Nepal \\ ${ }^{5}$ National Institute of Horticultural and Herbal Science, Rural Development Administration, 55365 Wanju, Republic of Korea \\ ${ }^{6}$ Department of Applied Plant Science, Kangwon National University, 24341 Chuncheon, Republic of Korea \\ ${ }^{7}$ Department of Botany, Mahendra Morang Adarsh Multiple Campus, Biratnagar, Tribhuvan University, Nepal
}

(Manuscript received 12 August 2020; accepted for publication 29 March 2021)

\begin{abstract}
Global food production needs to be increased in order to feed the world's growing population and at the same time, the reliance on inorganic fertilizers and pesticides should be minimized. To accomplish this goal, the various beneficial associations between plants and soil microorganisms should be explored. The soil microbes are bacteria, actinomycetes, viruses, fungi, nematode, and protozoa. They have an important soil function that has fulfilled several useful tasks in the soil system. Microbes support biological nitrogen fixation of different biological transformations that support the accumulation and utilization of key nutrients, support root and shoot growth processes, disease control, and improve soil quality in crop cultivation. Soil microbes offer nutrient-dense nourishment improved crop production and recycle soil solutions. They play an essential role in decomposing organic matter, cycling nutrients, and fertilizing the soil. Besides, they improve plant growth on various physiological parameters of plants by a number of mechanisms. The mechanism involved in growth promotion includes plant growth regulators, production of different metabolites, and conversion of atmospheric nitrogen into ammonia in direct and indirect ways. In addition, soil microbes offer resistance against diseases. This review outlines the significant impact of soil microbes on sustainable agricultural growth, the benefits of microbes in maintaining soil health, and their interactions.
\end{abstract}

Keywords: crop production, microbes, nutrients, soil health

\section{Introduction}

Soil contains millions of microbes involved in soil fertility betterment and crop production (Gougoulias et al., 2014). Soil microorganisms are important for the conservation of core soil processes linked to literal decomposition, nutrient availability, and crop yields. Soil physicochemical properties rely on the volume and quality of soil organic content, $\mathrm{pH}$, biomass density, and constraints of redox potential (Pandey et al., 2020). These all have important effects on the composition, dynamics, and soil structure of the microscopic culture (Lombard et al., 2011).

Soil assessments give valuable insight into nutrient requirements and assistance on fertilizer for crops (Shrestha et al., 2020a). Healthy and fertile soil functions as a robust living system offering various ecological functions that preserve the quality of water and enhance soil productivity (Shrestha, et al., 2020b) regulating the decomposition and recycling of soil nutrients, and the disposal of greenhouse gasses. Soil performance is directly related to the accumulation of water content for the greater productivity of crops and sustainable agriculture as the variety and involvement of soil microorganisms which are core elements of soil health (Glick, 2018). Doran and Zeiss (2000) have described soil health as "a soil's ability to act as an extremely important living system within the environment and within the borders of land use, to support living organisms' development, preserve or improve water and air quality and support animals and plants welfare". Soils are critical for the stability of the terrestrial ecosystems to remain intact or recover from disruption, including drought, climate change, insect infestations, deforestation, and exploitation of human capital, including agriculture (Ellert et al., 1997). Interactions between plants and microbes (mutual association) are essential areas of interest within the agricultural ecosystem and form the basis for all ecosystems (Be'langer and Avis, 
2002). Microorganisms play a major part in the absorption and decomposition of organic compounds by nitrogen, sulfur, and phosphorus. This impacts the global processing of nutrients and carbons (Pankhurst et al., 1997). In nitrogen, sulfur, and phosphorus oxidation, microorganisms are key participants in the decomposition of organic residues. This impacts nitrogen and carbon cycles worldwide (Pankhurst et al., 1997). The production and deterioration of raw products and synthetic organic compounds were also correlated with microorganisms (Torstensson et al., 1998). Microorganisms adapt rapidly to changes, so they react quickly to environmental conditions. The microorganisms that are best adapted will be the ones that flourish (Kennedy and Papendick, 1995). Soil microbiomes are implicated in the decomposion of soil organic matter, and both the existence of soil microorganisms and the quality of organic matter supplies depend on the rate of decomposition. Soil microorganisms are a core factor in the reaction through the different nutrient cycles as well as the soil carbon sequestration of the evolving environment in agriculture. Soil microorganisms are involved in many biogeochemical processes. We depict a concise summary of the role of various bacteria of the microorganisms (nitrogen fixation bacteria, azobacteria, actinomycetes, and rhizobacteria), fungi, algae, protozoa, and viruses in this scenario. Worldwide focus is required to enhance or rebuild the health of soils. Evaluation of indices of soil quality can expand our awareness of the factors that lead to sustainable agriculture. This review highlights research results on various categories of items of microorganisms found in soil and soil health management practices. It aims to enhance the awareness of soil microbe's benefits, interaction between soil and microbes, and ecological balance among plant, soil and microbes.

\section{Types of soil microorganisms}

\section{Bacteria}

Bacteria are so basic in structure that they are sometimes referred to as bags of enzymes and/or fertilizer soluble bags (Dick, 2009). In crop processing, soil bacteria have a key role as they take part in the processes that provide soil nutrients (Davison, 1988), boosting plant growth, e.g. plant hormone development, regulating or inhibiting plant pathogens, improving the composition of the soil as well as bioaccumulation and inorganic microbial leaching. Nitrogen content (10-30\% $\mathrm{N}, 3$ to $10 \mathrm{C}: \mathrm{N}$ ratio) in bacteria is higher than most microbes (Hoorman and Islam, 2010). Ingham (2009) defines the four main functional groupings of soil bacteria as decomposers, mutualists, pathogens, and lithotrophs. Each functional bacteria category plays a role in recycling soil nutrients.

Nitrogen fixing bacteria: Microorganisms employed to enhance the availability of nutrients, viz., nitrogen (by fixing atmosphere $\mathrm{N}$ ). Nitrogen plays an important role in the production of food and promotes plant growth (Pandey et al., 2020), it is also essential for the synthesis of cellular enzymes, chlorophyll, proteins, RNA and DNA. In agriculture currently,
$65 \%$ of the nitrogen is utilized through the process of biological nitrogen fixation and will remain to be vital in upcoming sustainable systems of crop production.

Bacteria commonly referred to as "Rhizobia" are believed to trigger the nodules at the roots of leguminous plants (and, rarely, stalks). The distinguished "bacteroid" types help in the fixation of nitrogen from the atmosphere within those nodules and subsequent ammonia is used as a fixed nitrogen supply. This symbiotic relationship is an exceptional niche for a bacterium and a specialized supply of nitrogen is obtained by the plants (Andrew et al., 2007). Bacteria such as Azotobacter, Azospirillum, Rhizobium, MesoRhizobium, SinoRhizobium are recognized for enhancing plant growth (Gonzalez et al., 2005).

Azospirillum: Nitrogen fixing Azaspirillum species correspond to the optional endophytic diazotrophic classes colonizing the surface and inside of roots, which is globally recognized as the bio-nitric nitrogen fixation. Azospirillum specifically promotes plants, which boost root and root growth and increase the rate of water and mineral intake per root, and maintain soil quality (Gonzalez et al., 2005).

Azotobacter. Azotobacter is a mandatory aerobe, even though at low oxygen concentration it can develop. The ecological spread of this bacterium is dynamic and is linked to different matters that decide that this bacterium occurs or is absent in a given soil (Sumbul et al., 2020).

Actinomycetes: Actinomycetes are gram-positive aerobic bacteria that belong to the order of Actinomycetes known by its substrate and aerial mycelium production. They form associations with some non-leguminous plants and fix $\mathrm{N}$, which is then available to both the host and other plants in the near vicinity. They have a crucial role in the cycling of organic matter; inhibit the growth of several plant pathogens in the rhizosphere. They decompose complex mixtures of polymer in dead plant, animal and fungal material resulting in production of many extracellular enzymes which are conductive to crop production (Bhatti et al., 2017). Actinomycetes inhabit the rhizosphere of agricultural crops, where they increase soil fertility through recycling of organic matter and solubilizing phosphate (Hozzein et al., 2019).

Cyanobacteria: Cyanobacteria are photoautotrophic gramnegative bacteria that are plentiful in several soils and take an active part in soil build-up and sustain fertility (Prasanna et al., 2009). Their impact on soil quality and plant tolerance to abiotic and biotic stresses, including plant diseases, is important. Cyanobacteria are sustainable sources of the biomass of the solubilized organic matter, that are mineralized by soil microorganisms (non-ribosomic peptides, isoprenoids, ribosomal peptides, alkaloids, and polyketides) which then in turn help farm crop growth (Kultschar et al., 2018). Cyanobacteria may improve $\mathrm{N}$ levels and the population of microorganisms in poor semiarid soils (Acea et al., 2003).

Rhizobacteria: The rhizosphere is the narrowed area of the soil that is specifically influenced by root secretions and related soil microbiomes (Antoun and Prevost, 2005). The term ,rhizosphere' was first used by Lorenz Hiltner to describe the effect of plant root secretion on edaphon. Plant- 
microbe interactions have attracted strong interest since the last century due to their crucial role in promoting plant growth (Hütsch et al., 2002). Rhizobacteria also play a significant role in enhancing soil structuring and the growth and stabilization of mineral phosphates, other nutrients, and soil aggregates, a-gluconase, antibiotics, and dehydrogenase, soil aggregates (Miller and Jastrow, 2000). The physical, chemical, and biological characteristics of the rhizosphere differ significantly from those of the surrounding soil. The rhizosphere is a quite special and narrow area of soil that is influenced by the plant root system (Giri et al., 2005). The number of microorganisms and invertebrates around the rhizosphere is higher than that in bulk soil. Rhizosphere microbes are considered to be the second set of genomes in plants and play a vital role in promoting plant growth and development, nutrient acquisition, inhibition of fungal plant pathogens. It should be noted that the structure of bacterial microbiota is a hereditary trait that has been verified in the rhizosphere of Arabidopsis and wheat, suggesting that its population could stabilize or undermine plant growth (Donaldson et al., 2016). Soil and crop health are the basis of the rhizobacterial population in the soil and vary from species to species (Tilak et al., 2005).

Microflora available in the soil (especially in the rhizosphere) has shown its potential to control the soil-borne disease by the method of biological control, and microbes used in this technique are referred to as bioagents or biocontrol agents (Cook et al., 1978). Rhizosphere composition of organic acids from root exudates is about $30 \%$ and its composition consists of simple carbohydrates, amino acids, and complex nutrients that support plant growth (Sandnes et al., 2005). The key elements of biological control is the colonization by microbes, especially bacteria, of the soil of rhizosphere or the external/internal root zone (Bahme and Schroth, 1987).

\section{Fungi}

Fungi are very productive inhabitants of soil, due to their high plasticity and ability to adopt different forms in response to adverse or unfavorable conditions (Sun et al., 2005). Fungi also perform an important part in the stabilization and decomposition of soil organic matter (Shah et al., 2021). Fungi transform dead organic matter into carbon dioxide, organic acids, and biomass. Many fungal species can function as an important biosorbent of toxic metals such as cadmium, copper, mercury, lead, and zinc, by collecting them in their fruiting bodies. The fungi are well-equipped for the preservation and restoration of the soil that consequently allows plants to thrive and flourish (Baldrian, 2003). Among all the microbes, fungi are more resistant than bacteria and actinomycetes, while others have quite the resistance for the fluctuating soil disruptions, or no soil disturbs (Hoorman and Islam, 2010; Meliani et al., 2012). In fact, they perform a significant part in the stabilization and decomposition of soil organic matter. In almost every environment, fungi can be observed and can live in a wide range of $\mathrm{pH}$ and temperature (Frac et al., 2015). Various biotic (plants and other organisms) and abiotic (soil pH, moisture, salinity, structure, and temperature) factors regulate the diversity and activity of fungi (Rouphael et al., 2015). Soil fungi can be classified into three functional groups, including (1) biological inspections, (2) ecosystem regulator, and (3) species involved in the decomposition of organic matter and transformation of compounds. For example, mycorrhizal fungi enhance plant growth through improved nutrient intake and defense from pathogens (Bagyaraj and Ashwin, 2017). The fungal population is highly affected by the plant community's diversity and composition, and in return trigger plant growth through mutualism, pathogenicity, and their impact on nutrient availability and cycling. Because of their capacity to generate a wide range of extracellular enzymes, they can break down all forms of organic matter, decompose soil components and thus control the carbon and nutrient balance.

\section{Algae}

Algae are a very wide and varied group of simple, usually autotrophic organisms which can perform photosynthesis and capture energy from sunlight; they also play a significant role in the soil where they are used as biofertilizer and soil stabilizers (Neilands, 1995). Like other species, algae contained in various types of soil can help the soil improve its characteristics such as carbon content, texture, and aeration (Ibraheem, 2007). Soil algae emit substances that promote growth, such as hormones, vitamins, amino acids, and organic acids, which in many ways influence other species (Wilson, 2006). The key roles and functions of algae in the soil are the maintenance of soil fertility, particularly in the tropical soils; they increase the organic carbon amount and other organic matter which helps to maintain soil health (Johns, 2017). By joining up soil particles in a manner that eliminates and avoids soil erosion, the algae help improve the potential for preservation of water in soils over longer periods of time; retain massive quantities of oxygen in the soil through the photosynthesis cycle and thereby help to control the depletion of nitrates; through leaching and drainage, especially in up-cropped soils; and helping in the weathering of rocks and building up of soil structure (Johns, 2017).

\section{Protozoa}

These are colorless, single-celled animal-like organisms. They are larger than bacteria, varying from a few microns to a few millimeters. Their population in arable soil ranges from 10,000 to 100,000 per gram of soil and they are abundant in surface soil (Bhatti et al., 2017). They can withstand adverse soil conditions, as they are characterized by a protected, dormant stage in their life cycle. Most protozoans derive their nutrition from feeding or ingesting soil bacteria and, thus, they play an important role in maintaining microbial/bacterial equilibrium in the soil. Some protozoa have been recently used as biological control agents against organisms that cause harmful diseases in plants.

\section{Viruses}

Soil viruses are very significant as they can have an effect on soil biology by moving genes from host to host and as a 
possible source for microbial mortality (Bhatti et al., 2017). Consequently, viruses are major players in global cycles, influencing the turnover and concentration of nutrients and gases (Mitchell, 1973); the field of soil virology is understudied in light of this significance. Studies are carried out on virus diversity and abundance in various geographic zones in order to investigate the role of viruses in plant health and soil quality. Viruses have been shown to be extremely common in all environments observed to date, including conditions under which bacterial species of the same ecosystem vary significantly.

\section{Benefits of soil microbes}

\section{Disease control}

Soil microbes play a significant role in the tolerance to plant diseases. They can prevent pathogen infection by inducing plant systemic disease resistance and by coating root surfaces to physically shield the plant from getting infected by pathogens. Soil microbes can make plants more resistant to an aggressive disease, thus opening new possibility for sustainable food production (University of York, 2019).

The industrial cultivation of the bacterium Bacillus thuringiensis (Bt) in the soil for caterpillars, pests is a well prominent framework for the usage of soil microbes to combat pests. Many Bt strains are often used for monitoring beetles and flies. A variety of strains have been produced as biocontrol agents of the fungal genus Trichoderma spp., primarily root disorders, for fungal plant diseases. In the management of insect pests, numerous genera of fungi are included. Efficacy of Bacillus spp. has been identified in various crop plants such as tomato, chili, brinjal, etc. to control different pathogens like R. solani, Colletotrichum acutatum, C. capsici, Pythium aphanidermatum and C. gloeosporioides (Abdul et al., 2007). Pseudomonas spp. exhibit antifungal activity against, $R$. solani, Pyricularia oryzae, and Xanthomonas oryzae pv. oryzae F. oxysporum, $f$. sp. udum both in vitro and field environments (Vidhyasekaran et al., 2001). Several soil-borne antagonists such as Trichoderma spp. are reported to control fungal wilt of tomato caused by F. sp. lycopersici and F. oxysporum (Singh et al., 2013).

\section{Availability of soil nutrients}

Soil microbes may contribute greatly to enrich the soil with nutrients which helps in maintaining soil productivity. It has been proved that biological fertilization is an efficient method to supply plants with their necessary nutrient. Three mechanisms are usually suggested to understand how microbial activity can promote plant growth:

(1) Manipulating the hormonal signaling of plants (Verbon and Liberman, 2016);

(2) Repelling or outcompeting pathogenic microbial strains (Mendes et al., 2013), and

(3) Enhancing plant mineral bioavailability (Bender et al., 2016).
Numerous experimental results have shown that the recycling of organic compounds and nutrients by the soil microorganisms is essential (Rai et al., 2016). The need for nutrients differs greatly according to soil productivity, climatic factors, crop characteristics, and production (Pandey et al., 2020). Soil microorganisms help plants by converting atmospheric elemental dinitrogen $\left(\mathrm{N}_{2}\right)$ into ammonia and are capable of nitrogen-fixing (bacteria possessing nitrogenase enzyme). Nitrogen-fixing and nutrient mineralization processes performed by soil, the microorganism is important in plant nutrition in natural ecosystems because these reactions metabolize recalcitrant forms of $\mathrm{N}, \mathrm{P}$, and $\mathrm{S}$ to liberate their elements providing plant nutrition (Modi et al., 2020). It must be noted briefly that in recent years, this proven paradigm has been somewhat challenged, as several studies have shown invasive species have a detrimental effect on nutrients availability and in direct plant uptake of various organic-N forms (Nasholm et al., 1998; Paungfoo-Lonhienne et al., 2008). Soil biota plays a crucial role in the modulation of primary production through control of decomposition and availability of nutrients as well as affects the root grazing and plant nutrient absorption, where invasive plants may disrupt soil associations and plant native plants and thereby encourage the success of invasions (Shah et al., 2020). Because of the low diffusivity of organic-N molecules in soil, microbes are better competitors for these nutrients and the findings of isotope labeling studies generally support the hypothesis that most organic- $\mathrm{N}$ is first assimilated by microbial taxa, and then assimilated by plants at microbial turnover (Richardson et al., 2009). Wilson et al. (2006) stated that iron contained in soil and microorganisms can cause growth inhibition, decrease in RNA and DNA synthesis, inhibition of sporulation, and can even alter cell morphology.

\section{Interaction between plants and soil microbes}

Soil microorganisms including bacteria, algae, fungi, and actinomycetes are important components which interact with the plants (Andreote et al., 2014). These soil microorganisms serve several essential roles and and sometimes cause negative effects. In the soil profile, the influence of soil biota is dynamic and nuanced, based on their location, the effect can be negative or beneficial (Parkin et al., 1996). In order to better control the interplay between crop microbes, the role environmental conditions must be taken into account. The dynamic relationships between bacteria and plants, and the soil system, as a factor for the soil formation and soil fertility, is evidence that soil has evolved over hundreds of years (Harrison, 2008)

Soil microbes have ability to produce auxins, gibberellins, $\mathrm{SA}, \mathrm{ABA}$, and cytokinins in plant tissues. Phytohormones produced by root-associated microbes may prove to be important metabolic engineering targets for inducing host tolerance to abiotic stresses (Egamberdieva et al., 2017).

Soil productivity and mineral rock formation involve a wide range of chemical, physical and biological interactions. The soil fertility rate is influenced by parameters such as 
topography, climatic conditions, period, rock form, plants, and microbes, which is why the nature and identity of the microbes in the soil determine the nutrient levels (Lombard et al., 2011). Soil microbes attach soil to roots, recycle nuts, decompose organic matter, and quickly respond to any changes in soil ecology, by providing an ideal indicator of which definite soil-environment functions (Jacoby et al., 2017). Crop productivity and soil fertility can be improved by various microbes, as well as by organic material bacteria. Climate change is also anticipated as a direct result of rising surface temperatures and indirect effects such as plant species or surface resources to influence soil microbial community structures (Deslippe et al., 2012). In non-disturbed grassland environments, decomposer Actinobacteria were more prevalent than in agricultural soils, whereas, for Bacteroidetes, the reverse trend has been identified (Acosta-Martínez et al., 2008). The conventional view is that soil microbes exist anywhere and the environment determines which species prevail, i.e. no dispersal limitations. The composition of a soil microbial culture, including its soil form, its mineral, and texture, the availability of nutrients $(C, N$, and $P)$, its moisture, the oxygen status as well as the related plant populations, has been influenced by this view (Bonkowsi et al., 2009).

Different types of soil microbes have different specific roles on plants (Table 1).

Table 1. Roles of soil microbes on plant

\begin{tabular}{|c|c|c|c|}
\hline Bacteria & Experimental conditions & Effects on plants & References \\
\hline $\begin{array}{l}\text { Bacillus } \\
\text { amyloliquesfaciens }\end{array}$ & Laboratory conditions & Increase root and shoot growth of rice & He et al., 2013 \\
\hline \multirow[t]{4}{*}{ Bacilus subtilis } & Field conditions & $\begin{array}{l}\text { Increase macro and micro nutrient absorption, } \\
\text { growth and plant production }\end{array}$ & Altuhaish et al., 2014 \\
\hline & Field conditions & Increase fresh and dry shoot and root weight & Turan et al., 2014 \\
\hline & $\begin{array}{l}\text { Laboratory, greenhouse and } \\
\text { field conditions }\end{array}$ & $\begin{array}{l}\text { Increased germination, shoot and root length, } \\
\text { grain yield of maize }\end{array}$ & Kifle and Laing, 2016 \\
\hline & Field conditions & Increased grain yield and straw weight of barley & Fröhlich et al., 2012 \\
\hline \multirow[t]{2}{*}{ Pseudomonas spp. } & $\begin{array}{l}\text { Pot experiment and field } \\
\text { conditions }\end{array}$ & $\begin{array}{l}\text { Improves germination, growth parameters and } \\
\text { yield of maize }\end{array}$ & Gholami et al., 2009 \\
\hline & Laboratory conditions & Growth stimulation of tomato plants & Gravel et al., 2007 \\
\hline Pseudomonas jessenii & $\begin{array}{l}\text { Greenhouse and field } \\
\text { conditions } \\
\text { Greenhouse conditions }\end{array}$ & $\begin{array}{l}\text { Increase yield and shoot dry weight of chickpea } \\
\text { Increase growth of tomato }\end{array}$ & Valverde et al., 2006 \\
\hline $\begin{array}{l}\text { Paenibacillus } \\
\text { mucilaginosus }\end{array}$ & Pot experiment & Improve growth of trifoliate orange seedlings & Wang et al., 2016 \\
\hline \multirow[t]{2}{*}{ Rhizophagus intraradices } & Greenhouse conditions & $\begin{array}{l}\text { Increase the plant growth, number of leaves, } \\
\text { plant height, shoot and root length and weight } \\
\text { of tea }\end{array}$ & $\begin{array}{l}\text { Sharma and Kayang, } \\
2017\end{array}$ \\
\hline & Field conditions & Increase growth of tomato & Mohamed et al., 2016 \\
\hline \multicolumn{4}{|l|}{ Fungi } \\
\hline \multirow[t]{3}{*}{ Trichodema spp. } & Laboratory conditions & $\begin{array}{l}\text { Improve growth and seed production of } \\
\text { soybean }\end{array}$ & Paradiso et al., 2017 \\
\hline & Laboratory conditions & Growth promoter of cowpea & Chagas et al., 2016 \\
\hline & Rhizobox experiment & Increase root length of maize & $\begin{array}{l}\text { Gomez-Munoz et al., } \\
2017\end{array}$ \\
\hline \multirow[t]{4}{*}{ Penicilium bilaii } & Field conditions & Increase grain yield of wheat & Ram et al., 2015 \\
\hline & Field conditions & $\begin{array}{l}\text { Increase root length and P-content in root of } \\
\text { pea }\end{array}$ & $\begin{array}{l}\text { Vessey and Heisinger, } \\
2001\end{array}$ \\
\hline & Pot experiment & $\begin{array}{l}\text { Improve germination and seedling growth of } \\
\text { wheat }\end{array}$ & El-Gremi et al., 2017 \\
\hline & $\begin{array}{l}\text { Greenhouse and laboratory } \\
\text { conditions }\end{array}$ & Increase potato yield & Buysens et al., 2016 \\
\hline \multirow[t]{3}{*}{ Trichoderma harzianum } & Pot experiment & $\begin{array}{l}\text { Increase shoot and root length, dry mass and } \\
\text { grain yield of Pigeon pea }\end{array}$ & Gupta et al., 2016 \\
\hline & Pot experiment & $\begin{array}{l}\text { Increased root length, growth and shoot dry } \\
\text { weight in Brassica nigra and melon }\end{array}$ & Galletti et al., 2015 \\
\hline & Pot experiment & Increase growth of Brassica juncea & Galletti et al., 2015 \\
\hline
\end{tabular}


Plants exhibit a diverse array of interactions with the soil microbes. Interactions between plants and soil microbes play an important role in enhancing plant growth and development.
The interactions of soil, plant and microbes along with their benefits are given in Figure 1.

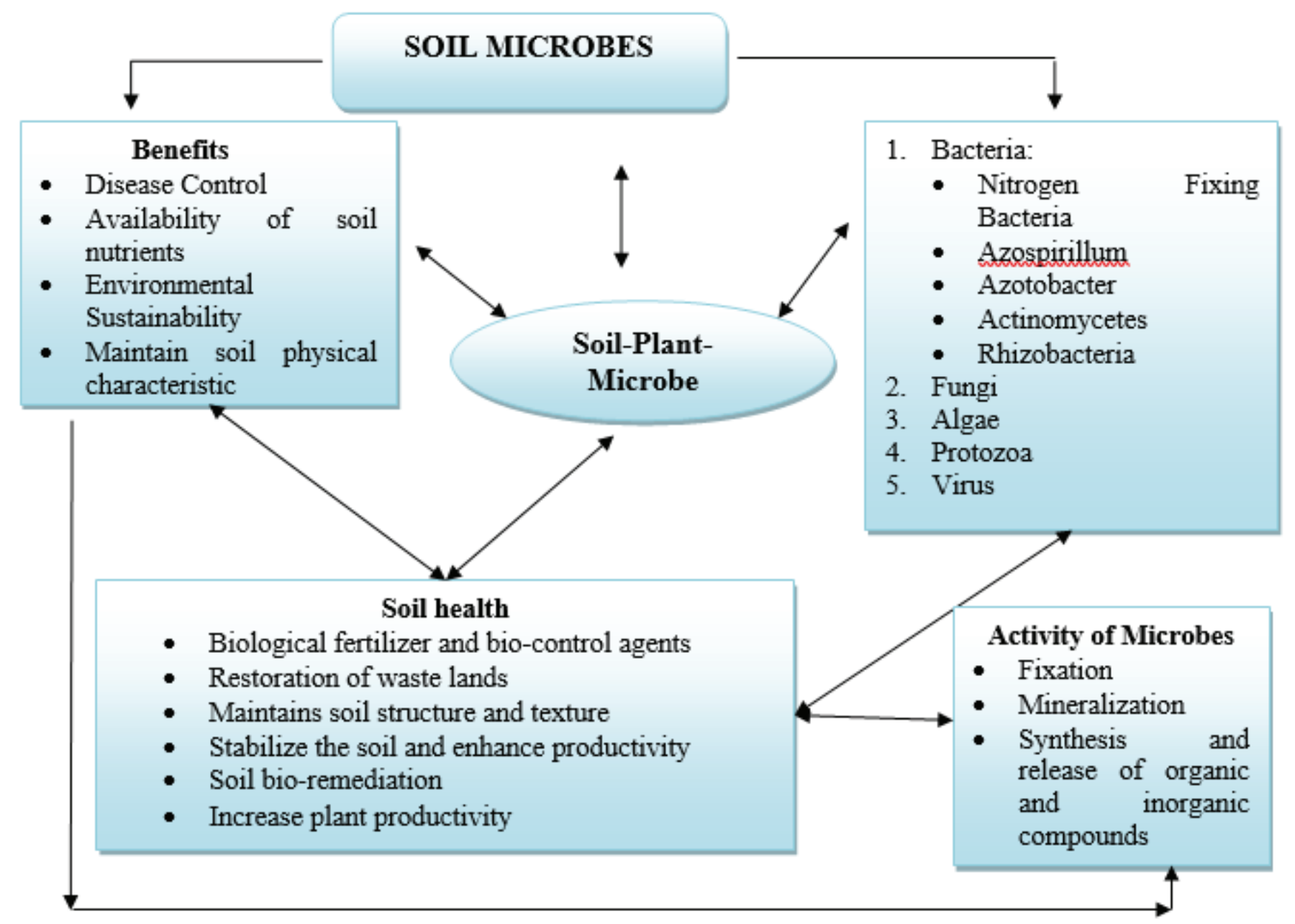

Figure 1. A conceptual theme demonstrating the important soil microbes with benefits and interactions of soil, plant and microbes (Tahat et al., 2021)

\section{Ecological balance among plants, soil and microbes}

Bio-fertilizer is also used in organic farming systems, but at present, the option of plant cultivars and microbial inoculants have little mechanistic understanding (Bender et al., 2016). Balanced utilization of organic fertilizers enhances fertilizer efficiency and physical, chemical, or biological soil environment, contributing to an increase in crop production (Tiwari et al., 2021). Plants interact with these soil-inhabiting species in several ways that cover the entire spectrum of ecological possibilities (competitive, exploitative, cooperative, commensal, and mutual). Many of the plantbased interactions have been focused in modern sciences on alleviating pathogens such as herbivory and infection, or reducing abiotic stress conditions. Yaish et al. (2016) established that microbial metabolism speeds up organic matter decomposition, facilitates nutrient mineralization, and enables plant absorbed nutrients. Efflux of $\mathrm{CO}_{2}$ from soil stems from two distinct factors such as root and microbial respiration rhizosphere and soil organic microbial decomposition. Importantly, nitrogen-fixing bacteria in the rhizosphere may be used to fix nitrogen in order to provide organic and inorganic nitrogen to plants (Dominati et al., 2010).

Protection of soil is therefore of high priority and a thorough understanding of ecosystem processes is an important factor in maintaining that soil remains healthy (Balasubramanian, 2017). This modification can likely allow for differential microbial studies in the soil health study and thus can serve as an excellent signal for improvements to soil health in microbial populations and activities (Kennedy et al., 1995; Pankhurst et al., 1997).

There are more microbes in a teaspoon of soil than there are people on the earth. Soils contain about 8 to 15 tons of bacteria, fungi, protozoa, nematodes, earthworms, and arthropods (Hoorman, 2020). The number and biomass of microbial species is given in Table 2. Changes in populations of microbes can in some cases precede significant changes in physical and chemical soil material, which can be a sign of early soil improvements or a warning of soil deterioration (Pankhurst et al., 1995). One example is the microbial biomass turnover rate. 
Table 2. Relative number and biomass of microbial species at $0-15 \mathrm{~cm}$ depth of soil

\begin{tabular}{lll}
\hline Microorganisms & Number $/ \mathrm{g}$ of soil & Biomass $\left(\mathrm{g} / \mathrm{m}^{2}\right)$ \\
\hline Fungi & $10^{5}-10^{6}$ & $100-1500$ \\
Bacteria & $10^{8}-10^{9}$ & $40-500$ \\
Algae & $10^{4}-10^{5}$ & $1-50$ \\
Nematodes & $10^{2}-10^{3}$ & Varies \\
Protozoa & $10^{3}-10^{4}$ & Varies \\
Actinomycetes & $10^{7}-10^{8}$ & $40-500$ \\
\hline
\end{tabular}

Source: Hoorman, 2020

\section{Conclusion}

The soil microbes are bacteria, actinomycetes, viruses, fungi, nematode, and protozoa. They produce plant growth regulators and metabolites that affect the plant growth and development. Soil microbes are critical to decomposing organic residues and recycling soil nutrients. They provide nutrients to crops, enhance soil health and crop outputs. Soil microbes play a significant part in the tolerance to plant diseases. Considering the environmental damage associated with use of chemical fertilization, a research priority on optimizing plant-soil microbe nutritional interactions is essential for more sustainable agricultural systems.

\section{Conflict of interest}

The authors have no conflict of interest.

\section{References}

Abdul S, Mansoor A, Abdul K, Singh P, Suman K, Alok K, Abdul S, Kumar A, Darokar MP, Shukla AK, Padmapriya T, Yaseen M, Dhawan PO, Zaim M, Nair V and Poovappallivadakethil AK, 2007. Novel strain of Bacillus as a bioinoculant, United States, 2, 25-30.

Acea MJ, Prieto Fernandez A and Diz Cid $\mathbf{N}, 2003$. Cyanobacterial inoculation of heated soils: Effect on microorganisms of $\mathrm{C}$ and $\mathrm{N}$ cycles and on chemical composition in soil surface. Soil Biology and Biochemistry, 35, 513-524.

Acosta-Martínez V, Dowd S, Sun Y and Allen V, 2008. Tagpyrosequencing analysis of bacterial diversity in a single soil type as affected by management and land use. Soil Biology and Biochemistry, 40, 762-770. doi: https://doi.org/10.1371/ journal.pone. 0017000

Altuhaish A and HamimTjahjoleksono A, 2014. Biofertilizer effects in combination with different drying system and storage period on growth and production of tomato plant under field conditions. Emirates Journal of Food and Agriculture, 26, 716722. doi: https://doi.org/10.9755/ejfa.v26i8.17178

Andreote FD, Gumiere T and Durrer A, 2014. Exploring interactions of plant microbiomes. Scientia Agricola, 71, 528539. doi: https://doi.org/10.1590/0103-9016-2014-0195

Andrew JW, Jonathan D, Andrew R, Lei S, Katsaridou NN,
Mikhail S and Rodionov AD, 2007. Living without Fur: the subtlety and complexity of iron-responsive gene regulation in the symbiotic bacterium Rhizobium and other a-proteobacteria. Biometals, 20, 501-511.

Antoun H and Prevost D, 2005. Ecology of plant growthpromoting rhizobacteria. In: PGPR: Biocontrol and Bio fertilization (ed. Z.A. Siddiqui). Springer, Dordrecht, 42, 31-38. doi: https://doi.org/10.1007/978-3-319-13401-7

Bagyaraj DJ and Ashwin R, 2017. Soil biodiversity: role in sustainable horticulture. Biodiversity Horticultural Crops, 1, 1-18. doi: https://doi.org/10.1007/978-3-319-13401-7

Bahme JB and Schroth MN, 1987. Spatial-temporal colonization patterns of arhizobacterium on underground organs of potatoes. Phytopathology, 81, 1093-1100. doi: 10.1094/Phyto-70-1078.

Balasubramanian A, 2017. Soil Forming Processes. Report number: 1, University of Mysore, Mysore, USA. doi: 10.13140/ RG.2.2.34636.00644

Baldrian P, 2003. Interactions of heavy metals with white-rot fungi. Enzyme and Microbial Technology, 32, 78-91. doi: https:// doi.org/10.1016/S0141-0229(02)00245-4

Be'langer RR and Avis TJ, 2002. Ecological processes and interactions occurring in leaf surface fungi. In: Phyllosphere Microbiology (eds. S.E. Lindow, E.I. Hecht-Poinar and V.J. Elliot). APS Press, St. Paul, MN, 69, 193- 207. doi: 10.1128/ AEM.69.4.1875-1883.2003

Bender SF, Wagg C and VanDerHeijden MGA, 2016. An underground revolution: biodiversity and soil ecological engineering for agricultural sustainability. Trends in Ecology \& Evolution, 31, 440-452. doi: 10.1016/j.tree.2016.02.016.

Bhatti AA, Haq S and Bhat RA, 2017. Actinomycetes benefaction role in soil and plant health. Microbial Pathogenesis, 111, 458-67. doi: 10.1016/j.micpath.2017.09.036

Bonkowski M, Villenave C and Griffiths B, 2009. Rhizosphere fauna: the functional and structural diversity of intimate interactions of soil fauna with plant roots. Plant Soil, 321, 213-233. doi: 10.1007/s11104-009-0013-2

Buysens C, Cesar V, Ferrais F, de Boulois HD and Declerck S, 2016. Inoculation of Medicago sativa cover crop with Rhizophagus irregularis and Trichoderma harzianum increases the yield of subsequently-grown potato under low nutrient conditions. Applied Soil Ecology, 105, 137143. doi:10.1088/1742-6596/1232/1/012022

Chagas LFB, De Castro, HG Colonia, BSO De, Carvalho MR and Miller LD, 2016. Efficiency of Trichoderma spp. as a growth promoter of cowpea (Vigna unguiculata) and analysis of phosphate solubilization and indole acetic acid synthesis. Brazilian Journal of Botany, 39, 437-445.

Cook RJ, Boosalis MG and Doupnik B, 1978. Influence of crop residues on plant diseases. (in)Crop Residue Management Systems. Biotechnol. Agron. Soc, 31,147-163. doi: https://doi. org/10.1094/PBIOMES-02-19-0010-RVW

Davison J, 1988. Plant beneficial bacteria. Biotechnology, 6 , 282-286

Deslippe JR, Hartmann M, Mohn BW and Simard SW, 2012 , 
Long term warming alters arctic soil microbial communities. FEMS Microbiology, Ecology, 82, 594-607.

doi: https://doi.org/10.1111/j.1574-6941.2012.01350.x

Dick R, 2009. Lecture on soil bacteria in soil Microbiology, personal collection of R. Dick, The Ohio state University School of Environment and Natural Resources, Columbus, 59, 15-20. doi: https://doi.org/10.1080/17429145.2011.597002

Dominati E, Patterson M and MacKay A, 2010. A framework for classifying and quantifying natural capital and ecosystem services of soils. Ecological Economics, 69, 1858-1868.

doi: 10.1016/j.ecolecon.2010.05.002

Donaldson GP, Lee SM and Mazmanian SK, 2016. Gut biogeography of the bacterial microbiota. Nature Reviews Microbiology, 14, 20-32. doi: 10.1016/j.ecolecon.2010.05.002

Egamberdieva D, Wirth SJ, Alqarawi AA, Abd_Allah EF and Hashem A, 2017. Phytohormones and beneficial microbes: essential components for plants to balance stress and fitness. Frontiers in microbiology, 8, 1-14. doi: https://doi. org/10.3389/fmicb.2017.02104

EI-Gremi SM, Draz IS and Youssef WAE, 2017. Biological control of pathogens associated with kernel black point disease of wheat. Crop Protection, 91, 13-19. doi: https://doi. org/10.1371/journal.pone.0213273

Ellert BH, Clapperton MJ and Anderson DW, 1997. An ecosystem perspective of soil quality. In: Soil Quality for Crop Production and Ecosystem Health (eds. E.G. Gregorich and M.R. Carter), Elsevier, Amsterdam, 74, 115-141.

Frąc M, Weber J, Gryta A, Dêbicka M, Kocowicz A and Jamroz E, 2017. Microbial functional diversity in podzol ectohumus horizons affected by alkaline fly ash in the vicinity of electric power plant. Geomicrobiology Journal, 34, 579-586. doi: https://doi.org/10.3389/fmicb.2018.00707

Fröhlich A, Buddrus-Schiemann K, Durner J, Hartmann A and Von Rad U, 2012. Response of barley to root colonization by Pseudomonas sp. DSMZ 13134 under laboratory, greenhouse, and field conditions. Journal of Plant Interactions, 7, 1-9.

Galletti S, Fornasier F, Cianchetta S and Lazzeri L, 2015. Soil incorporation of brassica materials and seed treatment with Trichoderma harzianum: Effects on melon growth and soil microbial activity. Industrial Crops and Products, 75, 73-78. doi: 10.1016/j.indcrop.2015.04.030

Gholami A, Shahsavani S and Nezarat S, 2009. The effect of plant growth promoting rhizobacteria (PGPR) on germination, seedling growth and yield of maize. International Journal of Biological, Biomolecular, Agricultural, Food and Biotechnological Engineering, 3, 9-12. doi: 10.5281/zenodo.1083385

Giri B, Giang PH, Kumari R, Prasad R and Varma A, 2005. Microbial Diversity in Soils, 151, 30-40.

doi: 10.1104/pp.109.147462

Glick B, 2018. Soil Microbes and Sustainable Agriculture. Pedosphere, 28, 167-169.

doi: https://doi.org/10.1016/S1002-0160(18)60020-7

Gomez-Munoz B, Pittroff SM, De Neergaard A, Jensen LS and Nicolaisen MH, 2017. Penicillium bilaii effects on maize growth and $P$ uptake from soil and localized sewage sludge in a rhizobox experiment. Biology and Fertility of Soils, 53, 2335. doi: 10.1007/s00374-016-1149-x

Gonzalez LJ, Rodelas B, Pozo C, Salmeron V, Martinez MV and Salmeron V, 2005. Liberation of amino acids by heterotrophic nitrogen fixing bacteria. Amino Acids, 28, 363-367. Gougoulias C, Clark JM and Shaw LJ, 2014. The role of soil microbes in the global carbon cycle: Tracking the below-ground microbial processing of plant-derived carbon for manipulating carbon dynamics in agricultural systems. Journal of the Science of Food and Agriculture, 94, 2362-2371.

doi: https://doi.org/10.1002/jsfa.6577

Grave IV, Antoun H and Tweddell RJ, 2007. Growth stimulation and fruit yield improvement of greenhouse tomato plants by inoculation with Pseudomonas putida or Trichoderma atroviride: Possible role of indole acetic acid (IAA). Soil Biology \& Biochemistry, 39, 1968-1977. doi: 10.1016/j. soilbio.2007.02.015

Gupta R, Bisaria VS and Sharma S, 2016. Response of rhizospheric bacterial communities of Cajanus cajan to application of bioinoculants and chemical fertilizers: A comparative study. European Journal of Soil Biology, 75, 107114. doi: 10.1016/j.ejsobi.2016.02.008

Harrison RB and Strahm B, 2008. Soil Formation. Encyclopedia of Ecology, 22, 3291-3295.

He P, Hao K, Blom J, Rückert Ch and Vater J, 2013. Genome sequence of the plant growth promoting strain Bacillus amyloliquefaciens subsp. Plantarum B9601-Y2 and expression of mersacidin and other secondary metabolites. Journal of Biotechnology, 164, 281-291. doi: 10.1016/j. jbiotec.2012.12.014.

Holeckova Z, Kulhánek M and Balík J, 2017. Use of active microrganisms in crop production - A review. Journal of Food Processing and Technology, 8, 696. doi: 10.4172/21577110.1000696

Hoorman JJ and Islam R, 2010. Understanding soil microbes and nutrient recycling, Fact sheet SAG-16-10. The Ohio State University, Columbus, USA.

Hoorman JJ, 2020. Understanding Soil Microbes and Nutrient Recycling. Ohio State University Extension, USA. https:// ohioline.osu.edu/factsheet/SAG-16

Hozzein WN, Abuelsoud W, Wadaan MA, Shuikan AM, Selim S, Al Jaouni S and AbdElgawad H, 2019. Exploring the potential of actinomycetes in improving soil fertility and grain quality of economically important cereals. Science of the Total Environment, 651, 2787-2798.

Hütsch BW, Augustin J and Merbach W, 2002. Plant rhizodeposition - an important source for carbon turnover in soils. Journal of Plant Nutrition and Soil Science, 165, 397-407. doi: https://doi.org/10.1002/jpln.201100300

Ibraheem IBM, 2007. Cyanobacteria as alternative biological conditioners for bioremediation of barren soil. Studies on nitrogen fixing Cyanobacteria. Thesis for MSc, Botany Department, Faculty of Science, Beni-Suef University, BeniSuef, Egypt, 8, 99-116.

Ingham ER, 2009. Soil Biology Primer. Soil Fungus, Ankeny 
IA: Soil and Water Conservation Society, 4, 22-23. Jacoby R, Peukert M, Succurro A, Koprivova A and Kopriva S, 2017. The role of soil microorganisms in plant mineral nutrition-current knowledge and future directions. Frontiers in Plant Science, 8, 1617.

doi: https://doi.org/10.3389/fpls.2017.01617

Johns C, 2017. Living Soils: The Role of microorganisms in soil health. Future Directions International Pty Ltd. Suite 5, 202 Hampden Road, Nedlands WA 6009, Australia.

Kennedy AC and Papendick RI, 1995. Microbial characteristics of soil quality. Journal of Soil and Water Conservation, 50, 243-248. Kifle MH and Laing MD, 2016. Effects of selected diazotrophs on maize growth. Frontiers in Plant Science, 7, 1429. doi: https:// doi.org/10.3389/fpls.2016.01429

Kultschar B and Llewellyn C, 2018. Secondary metabolites in cyanobacteria. In: Secondary Metabolites-Sources and Applications; InTech: London, UK, 2, 23-36.

Lombard N, Prestat E, van Elsas JD and Simonet P, 2011. Soil-specific limitations for access and analysis of soil microbial communities by metagenomics. FEMS Microbiology Ecology, 78, 31-49. doi: https://doi.org/10.1111/j.15746941.2011.01140.x

Meliani A, Bensoltane A and Mederbel K, 2012. Microbial diversity and abundance in soil: related to plant and soil type. American Journal of Plant Nutrition and Fertilization Technology, 2, 10-18.

Mendes R, Garbeva P and Raaijmakers JM, 2013. The rhizosphere microbiome: significance of plant beneficial, plant pathogenic, and human pathogenic microorganisms. FEMS Microbiology Reviews, 37, 634-663.

Mitchell JE, 1973. The mechanism of biological control of plant diseases. Soil Biology \& Biochemistry, 5, 721-728.

Modi B, Kumari Shah K, Shrestha J, Shrestha P, Basnet A, Tiwari I and Prasad Aryal S, 2020. Morphology, biological activity, chemical composition, and medicinal value of Tinospora Cordifolia (willd.) Miers. Advanced Journal of Chemistry, Section B, 36-54.

Mohamed HA, Barry KM and Measham PF, 2016. The role of arbuscular mycorrhizal fungi in establishment and water balance of tomato seedlings and sweet cherry cuttings in low phosphorous soil. Acta Horticulture, 1112, 109-115.

Muller DB, Vogel C, Bai Y and Vorholt JA, 2016. The plant microbiota: systems-level insights and perspectives in Annual Review of Genetics, Bonini NM, (Palo Alto CA: Annual Reviews, 50, 211-234.

Nasholm T, Ekblad A, Nordin A, Giesler R, Hogberg M and Hogberg P, 1998. Boreal forest plants take up organic nitrogen. Nature, 392, 914-916.

Neilands JB, 1995. Siderophores: structure and function of microbial iron transport compounds. Journal of Biological Chemistry, 270, 26723-26726. doi: 10.1074/jbc.270.45.26723

Pandey H, Maaren I, Shah K and Maraseni T, 2020. Response of topographic and biodiversity variables on biomass and carbon density in community forests of Himalayan foot-hills. Journal of Forest and Livelihood, 19, 51-65.
Pandey M, Shrestha J, Subedi S and SI K, 2020. Role of nutrients in wheat: A Review. 1, 18-23.

doi: https://doi.org/10.26480/trab.01.2020.18.23

Pankhurst CE, Doube BM and Gupta VSR, 1997. Biological indicators of soil health: Synthesis. In: Biological Indicators of Soil Health. Pankhurst, CAB International, 419-435.

doi: https://doi.org/10.1111/j.1469-8137.1998.194-3.x

Paradiso R, Arena C, DeMicco V, Giordano M, Aronne G and DePascale S, 2017. Changes in leaf anatomical traits enhanced photosynthetic activity of soybean grown in hydroponics with plant growth-promoting microorganisms. Frontier in Plant Science, 8, 674. doi: https://doi.org/10.3389/ fpls.2017.00674

Parkin TB, Doran JW and Vizcaino EF, 1996. Field and laboratory tests of soil respiration. In: Methods for assessing soil quality (eds. J.W. Doran and A.J. Jones), pp. 231-246, SSSA Spec. Publ. 49, SSSA, Madison, WI.

Prasanna R, Jaiswal P, Nayak S, Sood A and Kaushik $B D, 2009$. Cyanobacterial diversity in the rhizosphere of rice and its ecological significance. Indian Journal of Microbiology, 49, 89-97.

Rai AK, Singh DP, Prabha R, Kumar M and Sharma L, 2016. Microbial Inoculants: Identification, Characterization, and Applications in the Field, Springer India.

Ram H, Malik SS, Dhaliwal SS, Kumar B and Singh Y, 2015. Growth and productivity of wheat affected by phosphorussolubilizing fungi and phosphorus levels. Plant, Soil and Environment, 61,122-126.

doi: https://doi.org/10.17221/982/2014-PSE

Richardson AE, Barea JM, Mcneill AM and PrigentCombaret C, 2009 Acquisition of phosphorus and nitrogen in the rhizosphere and plant growth promotion by microorganisms. Plant and Soil, 321-339. doi: 10.1038/nplants.2015.221

RouphaelY, Franken P, Schneider C, Schwarz D, Giovannetti M and Agnolucci M, 2015. Arbuscular mycorrhizal fungi act as biostimulants in horticultural crops. Scientia Horticulturae, 196, 91-108. doi: 10.1016/j.scienta.2015.09.002

Sandnes A, Eldhuset TD and Wollebaek G, 2005. Organic acids in root exudates and soil solution of Norway spruce and silver birch. Soil Biology and Biochemistry, 37, 259-269.

doi: 10.1016/j.soilbio.2004.07.036

Shah KK, Tiwari I, Modi B, Pandey HP, Subedi S and Shrestha J, 2021. Shisham (Dalbergia sissoo) decline by dieback disease, root pathogens and their management: A review. Journal of Agriculture and Natural Resources, 4, 255272. doi: https://doi.org/10.3126/janr.v4i2.33915

Sharma D and Kayang H, 2017. Effects of arbuscular mycorrhizal fungi (amf) on camellia sinensis (I.) o. kuntze under greenhouse conditions. Journal of Experimental Biology and Agricultural Sciences, 5, 235-241. doi: http://dx.doi. org/10.18006/2017.5(2).235.241

Sharma R, Khokhar MK, Jat RL and Khandelwal SK, 2012. Role of algae and cyanobacteria in sustainable agriculture system. Wudpecker Journal of Agricultural Research, 1, 381388. 
Shrestha J, Kandel M, Subedi S and SI K, 2020a. Role of nutrients in rice (Oryza sativa L.): A review. Agrica, 9, 53-62. doi: https://doi.org/10.5958/2394-448X.2020.00008.5

Shrestha J, Shah KK and Timsina KP, 2020b. Effects of different fertilizers on growth and productivity of rice (Oryza sativa L.): A review. International Journal of Global Science Research, 7. doi: https://doi.org/10.26540/ijgsr.v7.i1.2020.151 Singh G, Saha S, Sharma BK, Garg R, Rai AB and Singh $\mathbf{R P}$, 2013. Evaluation of selected antagonists against Fusarium wilt disease of tomato. J. Interacad, 17, 234-239.

Sumbul A, Ansari R, Rizvi R and Mahmood I, 2020. Azotobacter: A potential bio-fertilizer for soil and plant health management. Saudi Journal of Biological Sciences, 27. doi: https://doi.org/10.1016/j.sjbs.2020.08.004

Sun JM, Irzykowski W, Jedryczka M and Han FX, 2005. Analysis of the genetic structure of Sclerotinia sclerotiorum (Lib.) de Bary populations from different regions and host plants by random amplified polymorphic DNA markers. Journal of Integrative Plant Biology, 47, 385-395.

Tahat M, Alananbeh K, Othman Y and Leskovar D, 2020. Soil Health and sustainable agriculture. Sustainability, 12, 4859. https://doi.org/10.3390/su12124859

Tilak K, Ranganayaki N, Pal KK, Saxena AK, Nautiyal CS, Mittal S, Tripathi AK and Johri BN, 2005. Diversity of plant growth and soil health supporting bacteria. Current Science, 89, 136-150. doi: https://doi.org/10.18393/ejss.650546

Tiwari I, Shah KK, Tripathi S, Modi B, Subedi S and Shrestha J, 2021. Late blight of potato and its management through the application of different fungicides and organic amendments: A review. Journal of Agriculture and Natural Resources, 4, 301320. doi: https://doi.org/10.3126/janr.v4i1.33374

Torstensson L, Pell M and Stenberg B, 1998. Need of a strategy for evaluation of arable soil quality. AMBIO: A Journal of the Human Environment, 27, 4-8.

doi: https://doi.org/10.1023/B:ECTX.0000012404.08568.e2

Turan M, Ekinci M, Yildirim E, Gunes A, Karagoz K, Kotan R and Dursun A, 2014. Plant growth-promoting rhizobacteria improved growth, nutrient, and hormone content of cabbage
(Brassica oleracea) seedlings. Turkish Journal of Agriculture and Forestry, 38, 327-333. doi: doi:10,3906/tar-1308-62

University of York, 2019. Soil microbes play a key role in plant disease resistance. ScienceDaily. Retrieved February 11, 2021 from www.sciencedaily.com/releases/2019/09/190925154024.htm Valverde A, Burgos A, Fiscella T, Rivas R, Velazquez E, Rodríguez-Barrueco C, Cervantes $\mathrm{E}$, Chamber $\mathrm{M}$ and Igual $J, 2006$. Differential effects of coinoculations with Pseudomonas jessenii PS06 (a phosphatesolubilizing bacterium) and Mesorhizobium ciceri C-2/2 strains on the growth and seed yield of chickpea under greenhouse and field conditions. Plant and Soil, 287, 43-50.

doi: 10.21930/agrosavia.manual-18

Verbon EH and Liberman LM, 2016. Beneficial microbes affect endogenous mechanisms controlling root development. Trends in Plant Science, 21, 218-229. doi: 10.4141/p00-083

Vessey KJ and Heisinger KG, 2001. Effect of Penicillium bilaii inoculation and phosphorus fertilisation on root and shoot parameters of field-grown pea. Canadian Journal of Plant Science, 81, 361-366.

doi: https://doi.org/10.3389/fmicb.2017.01895

Vidhyasekaran P, Kamala N, Ramanathan A, Rajappan A, Paranidhran V and Velazhahan R, 2001. Induction of systemic resistance by Pseudomonas fluorescens Pfl against Xanthomonas oryzae pv. oryzae in rice leaves. Phytoparasitica, 29, 155-166. doi: https://doi.org/10.1073/ pnas. 1320054111

Wang P, Wu SH, Wen MX, Wang $Y$ and Wu QS, 2016. Effects of combined inoculation with Rhizophagus intraradices and Paenibacillus mucilaginosus on plant growth, root morphology, and physiological status of trifoliate orange (Poncirus trifoliata L. Raf.) seedlings under different levels of phosphorus. Scientific Horticulture, 205, 97-105. doi: 10.3923/ biotech.2017.34.39

Wilson MK, Abergel RJ, Raymond KN, Arceneaux JEL and Byers BR, 2006. Siderophores of Bacillus anthracis, Bacilluscereus, and Bacillus thuringiensis. Biochemical and Biophysical Research Communications, 348, 320-32. 